\title{
Learning from reflection: A case of a post-sojourn debriefing workshop with EFL university students
}

\author{
Defne Erdem Mete ${ }^{\text {a } * \text { (D) }}$ \\ ${ }^{a}$ Selçuk University, Konya, Turkey
}

\section{APA Citation:}

Erdem Mete, D. (2019). Learning from reflection: A case of a post-sojourn debriefing workshop with EFL university students. Journal of Language and Linguistic Studies, 15(4), 1376-1394.

Submission Date:01/11/2019

Acceptance Date:07/12/2019

\begin{abstract}
Experiential learning activities have been largely used in education including English language teaching. Study abroad programs offer unique opportunities for learning from experience. Maximising learning from the sojourn experiences should be a major objective of higher education institutions with study abroad programs and designing post-sojourn debriefing workshops is crucial for this purpose. In this qualitative case study, Kolb's (1984) Experiential Learning Model was used to design a post-sojourn debriefing workshop for three Turkish EFL university students. The workshop was supported by the Cross-cultural Reflective Model (Dressler et al., 2018) designed for reflective writing about sojourn experiences. Critical incidents written by the participants of the study were the main materials to be used in the workshop and reflection was a continuous process throughout the study. Data were collected from reflection reports, reflection forms, written critical incidents, interview transcripts and field notes. Findings of the study revealed that an experiential post-sojourn debriefing workshop guided by a model of reflective writing for EFL university students was especially beneficial for enhancing intercultural learning, facilitating critical reflection and increasing motivation to share sojourn experiences. It was also highlighted that the use of critical incidents played a significant role for reflection in the workshop.
\end{abstract}

(C) 2019 JLLS and the Authors - Published by JLLS.

Keywords: EFL; experiential learning; post-sojourn debriefing workshop; reflective writing; critical incident

\section{Introduction}

The sojourn experiences of higher education learners provide a rich resource not only for improving the quality of study abroad programs but also for enabling valuable experiential learning. However, without the crucial element of reflection, it would be almost impossible to facilitate learning from experience. According to Dressler, Becker, Kawalilak and Arthur (2018), "reflective writing as a process and practice can be used to engage deeper experiential learning” (p. 491). Although there are studies on the use of experiential learning and reflective writing models in language teaching, empirical studies which investigate their integrated use about the sojourn experiences of English language learners are very limited. This study is an attempt to fill this gap by presenting findings of a qualitative case study designed as a post-sojourn debriefing workshop based on an experiential learning model which is guided

\footnotetext{
* Corresponding author. Tel.: +90 3322231451
}

E-mail address: defnemete@selcuk.edu.tr 
by the Cross-cultural Reflective Model (CCR) suggested by Dressler et al. (2018). Another significance of the study is that it offers an examination of the CCR model in practice through using critical incidents as structured reflection tools.

The objective of the workshop was to help Turkish EFL university students reflect on and enhance their learning from what they experienced in their sojourn experiences as well as in the reflective writing activities facilitated throughout the workshop. Reflective classroom discussions based on an experiential learning approach were combined with reflective writing practices outside the classroom. Three Turkish students studying at an English Language and Literature department of a state university in Turkey participated in the study. The students were chosen among returning study abroad students. Data were collected from reflective writing samples of the students including reflection reports, reflection forms and critical incidents, as well as a semi-structured interview and field notes.

\subsection{Literature review}

Experiential learning methods have been widely used in education including language teaching (Battles, 2004; Boggu \& Sundarsingh, 2016; Knutson, 2003). Reflection is a vital component of experiential learning which is foregrounded on the idea that experience can be transformed into learning only after reflection. Kolb's (1984) Experiential Learning Model includes four stages which are Concrete Experience, Reflective Observation, Abstract Conceptualization and Active Experimentation. In the Concrete Experience stage, the experience of the learner forms the basis of learning. The second stage of Reflective Observation provides critical examination of the experience from different perspectives. In Abstract Conceptualization, the learners relate their conclusions to concepts. Finally, they make a plan and take action in the Active Experimentation stage. Experiential learning stages provide a useful framework for debriefing which is a term used to refer to the question and answer sessions with learners. Kolb's model has formed the basis of models for reflective writing (Gibbs, 1988; Johns, 2010; Rolfe, Freshwater \& Jasper, 2001). Based on these experiential learning models, Dressler et al.'s (2018) CCR Model is designed especially for facilitating reflective writing after the sojourn experience in debriefing workshops and for pre-service teachers. Dressler et al. (2018) state that when structuring reflective writing, guiding questions and prompts should be selected with care by educators. The model consists of the stages of Imagine, Describe, Reflect, Make Meaning, Take Learning Forward and Share (see Appendix I).

Personal narratives such as diaries are found beneficial for assessing the intercultural learning of sojourners (Andrew, 2012; Callen, 1999; Jackson, 2005; Kilianska-Przybylo, 2012; Pellegrino, 1998; Wagner \& Magistrale, 1999; Williams, 2017). Williams (2017) emphasizes the importance of providing structure in reflective writing practices. Spencer-Oatey and Davidson (2013) suggest a structured template with prompts which provides guidance for recording and reflecting on the intercultural encounters. The Autobiography of Intercultural Encounters (AIE) (Byram et al., 2009), published by the Council of Europe, was used with English language learners and it was found that implementing this model was useful for facilitating intercultural reflection (Koyama, Matsumoto \& Ohno, 2012; Méndez Garcia, 2017). Writing narratives about intercultural encounters by using AIE as a model was investigated by Erdem Mete (2018) in a case study. It was found that AIE, as a model with detailed guiding questions, was beneficial for the learner to think about the neglected issues about the encounter and write a reflection more critically.

The critical incident technique, first coined by Flanagan (1954), was used to develop psychological principles based on the observations of human behaviour. Narrative reflection through critical incidents has been investigated in different fields of education (Tran, Admiraal \& Saab, 2019), as well as in the context of English language teaching (Farrell, 2013; Thiel, 1999; Walker, 2015). In the field of intercultural communication, Wight (1995) defines critical incidents as "brief descriptions of situations 
in which there is a misunderstanding, problem or conflict arising from cultural differences between interacting parties or where there is a problem of cross-cultural adaptation" (p.128). Analysing critical incidents about intercultural encounters is suggested in intercultural training for developing intercultural competence (Baxter \& Ramsey, 1996; Bennett, 1995; Wight, 1995). Educational interventions for developing the pre-sojourn, sojourn and post-sojourn students' intercultural learning in higher education contexts were investigated (Hepple, 2018; Lee, 2018; McKinnon, 2018). More specifically, implementing critical incident analysis for enhancing intercultural sensitivity before, during and after the study abroad experience of university students was found advantageous (Arthur, 2001; McAllister, Whiteford, Hill, Thomas \& Fitzgerald, 2006; Schnickel, 2014). However, studies integrating experiential learning with reflective writing practices in post-sojourn interventions for EFL students in higher education are limited.

\subsection{Research questions}

The study aimed to find an answer for the following research question:

"What do the students' self-reflections and comments reveal about the reflective learning facilitated through the post-sojourn debriefing workshop and supported by the Cross-cultural Reflective Model?"

It was hypothesized that themes related to both intercultural learning about the sojourn experience and learning enhanced through the reflective practices in the workshop would appear in the findings.

\section{Method}

\subsection{Sample / Participants}

The study was carried out at the English Language and Literature department of a state university in Turkey during the Spring semester of the 2018-2019 academic year. The students at this department learn English as a foreign language. They have the option of taking intensive pedagogical formation courses at the last year of their bachelor program, which enables them to be awarded a teaching certificate and work as English teachers after graduation. Three fourth-year students who returned from their sojourn stays and who volunteered to participate in the workshop took part in the study. They had been studying English as a foreign language and two of them wanted to be English teachers after graduation. Therefore, in order to be qualified as an English teacher, two of the students, S1 and S3, had been taking pedagogical formation courses at the time the study was carried out.

All of the students had an age range of 20-21 when they were abroad as exchange students in their university education. Two participants were female and one participant was male. In order to respect the privacy of the students, they were referred as S1, S2 and S3 in the study. Two of the students, S2 and S3, had been abroad for one week with the Comenius program when they were at high school. In terms of prior cross-cultural training, S2 was the only student who received such kind of training during the Comenius program that he had attended in Switzerland for a week. This training mainly involved a comparison of the required education for certain professions in different countries. Although S3 had been abroad as a Comenius student as well, she stated that the project she was involved in did not include cross-cultural issues. Table 1 shows background information about the participants in terms of the participated program abroad, sojourn duration and the countries visited during their sojourn stays. As seen in the table, all of the students participated in Erasmus programs. It had been almost one year since the last sojourn stay of S1, while this time was nine months for S2 and eighteen months for S3. 
Table 1. Background of the Participants

\begin{tabular}{|c|c|c|c|}
\hline & Participated Program Abroad & Sojourn Duration & Countries Visited \\
\hline $\begin{array}{l}\text { S1 } \\
\text { (Female) }\end{array}$ & Erasmus Exchange (Poland) & $\begin{array}{l}\text { October 2017- } \\
\text { February } 2018\end{array}$ & $\begin{array}{l}\text { Czech Republic, Austria, Hungary, } \\
\text { Netherlands, Italy, Spain, Portugal, } \\
\text { Belgium, Germany }\end{array}$ \\
\hline $\begin{array}{l}\text { S2 } \\
(\text { Male) }\end{array}$ & $\begin{array}{l}\text { Erasmus Exchange (Poland) } \\
\text { Comenius (Switzerland) }\end{array}$ & $\begin{array}{l}\text { February 2018- June } \\
2018 \\
\text { May } 2015 \\
\text { (one week) }\end{array}$ & $\begin{array}{l}\text { Germany, Austria, Spain, } \\
\text { Czech Republic }\end{array}$ \\
\hline $\begin{array}{l}\text { S3 } \\
\text { (Female) }\end{array}$ & $\begin{array}{l}\text { Erasmus Project (Italy) } \\
\text { Erasmus Internship (Portugal) } \\
\text { Comenius (Czech Republic) }\end{array}$ & $\begin{array}{l}\text { September } 2017 \\
\text { (ten days) } \\
\text { June } 2017 \\
\text { September } 2017 \\
\text { March } 2013 \\
\text { (one week) }\end{array}$ & $\begin{array}{l}\text { Albania, Armenia, Italy, Spain } \\
\text { Czech Republic, France }\end{array}$ \\
\hline
\end{tabular}

\subsection{Instrument(s)}

In order to find an answer to the research question, five data collection instruments were used: a reflection report, a reflection form, written critical incidents, field notes and a semi-structured interview. These instruments were expected to demonstrate participants' critical reflection as they showed their opinions about the content of the workshop. As the instructor of the workshop, the researcher took field notes at each session. The students were required to write a reflection report and a reflection form after the workshop for each week. The instruction of the reflection form was: "What do you think about the discussions you had with your friends in today's session? Write about what you found useful or not." In the reflection report, the students wrote their answer for the instruction: "Analyze an incident that you found interesting or important which we discussed in class today. What is the importance of this incident for you?" The participants also revised their own critical incidents which were discussed in each session and edited them by using the CCR Model as a framework. The instruction given for this revision process was: "Your critical incidents will be the final product of this workshop and your friends planning to go abroad will read them. With this aim to share your experiences and to provide the necessary details, revise and edit your critical incident by using the CCR Model as a framework." One week after the end of the pedagogical intervention, a semi-structured interview was conducted in which the participants' opinions about the strengths and weaknesses of the workshop were addressed. 


\subsection{Data collection procedures}

The workshop was carried out during the Spring semester of the 2018-2019 academic year. It included four sessions and each session lasted for one hour a week. Critical incidents collected from the students formed the main material of the workshop. Therefore, two weeks before the workshop started, the participants who voluntered to take part in the study were required to write critical incidents about their sojourn experiences. The instruction given at this stage was: "Please write one paragraph about an incident which you experienced abroad and which was somehow problematic or confusing for you because of cultural differences. "Each student wrote at least ten critical incidents.

At the end of the two weeks, the students submitted 32 incidents in total. After reading the incidents, three researchers classified the critical incidents based on the Iceberg Model of Culture's (Hall, 1976) three sections. The three sections of the model were referred in this study as A, B and C; A representing 'surface culture', B representing 'just below the surface culture' and C representing 'deep culture' (see Appendix IV). Incidents which could be discussed by referring to two sections of the model were classified as A-B or B-C. Through a progression of incidents from 'surface culture' to 'deep culture', this classification enabled to determine which critical incidents would be the material for each session. It also enabled students to read incidents belonging to the same categories each week.

After collecting and classifying critical incidents, it was seen that almost half of the incidents were related to the surface culture (14 out of 32). In order to avoid repetition of very similar incidents and because of the time limit of the workshop sessions, 5 incidents were omitted. Eventually, 27 critical incidents were chosen to be included in the workshop. Critical incidents related to section A were read in the first session; section A-B in the second session, section B-C in the third session and finally, section $\mathrm{C}$ in the fourth session of the workshop (see Appendix II).

Reflection was facilitated through reflective discussions in the workshop and by written reflection reports, reflection forms and revised critical incidents after the workshop. In the first session, the students were given brief information on the Iceberg Model of Culture (Hall, 1976). Inclusion of this model in the workshop provided a framework to have discussions about which section of the iceberg seemed to be more appropriate for the critical incident being discussed. In each session, the students read the critical incidents that were written by themselves and also by their peers. It was assured that all of the sessions included an incident written by each participant. The reading of each incident, both silently and aloud, was followed by a discussion guided by the researcher. Both Kolb's Experiential Learning Cycle and the CCR Model provided the frameworks for the facilitated 'directed questioning' as suggested by Baxter and Ramsey (1996, p. 212).

In this study, the Concrete Experience stage of Kolb's (1984) model in each session of the workshop was established by reading the critical incidents compiled beforehand. This stage also constituted the Imagine and Describe components of the CCR Model. After reading each incident in the workshop, by addressing questions corresponding to Kolb's stages of Reflective Observation, Abstract Conceptualization and Active Experimentation, students were guided to reflect on their experiences as suggested by Battles (2004). The questions included "Who else had a similar experience? Did you feel the same way or differently? What actually happened in this experience? Why is it significant? Do you see any cultural values operating here? What can we conclude from that? What did you learn? How would you do this again differently? "When necessary, these questions were also supplemented by those from the Reflect, Make Meaning and Take Learning Forward components of the CCR Model (see Appendix I). In this way, students also got familiar with the CCR Model in the workshop. The final 'Share' component of the CCR Model enabled not only continuous sharing of opinions and experiences in the workshop, but also a revision of the critical incidents by their writers to give them their final form. The students were told that the final versions of their critical incidents would be collected for future 
sojourn students to read. This enabled students to see their final written critical incidents as a product of the workshop. Therefore, at the end of each session, students were required to think about: "How would you improve your critical incident for a wider audience of students who will read your incidents before departure?" It was important to make the students feel free to make the appropriate revisions as they preferred. Therefore, the students were not told to revise their critical incidents in a specific way. The participants sent their reflection forms, reflection reports and revised critical incidents to the researcher by e-mail one day after each session.

\subsection{Data analysis}

In this case study, a qualitative analysis was performed in order to get an in-depth understanding of the data. The five data collection instruments were analyzed to find similar themes (Patton, 2002). Based on the principles of grounded theory (Strauss \& Corbin, 1998), the recurring patterns in the data were classified. In order to assure validity, the patterns related to the research question in each data were compared to the previous emerging patterns through a process of triangulation. Two other researchers were involved in the process to assure reliability. Data were coded separately by the researchers and after each phase of coding, the codes were compared and an agreement was reached.

First, the reflection papers consisting of reflection forms and reports were read and the data were divided into meaningful units of analysis. Then, the field notes were examined for finding similar patterns. The next step of triangulation was to relate the common patterns found in the interview to the findings of reflection papers and field notes. Finally, the first and final versions of the critical incidents written by the students were reviewed and compared. Through this comparative process, units of analysis formed the emerging themes shared by the participants.

\section{Results and Discussion}

As the themes show, the students' self-reflections and comments reveal reflective learning which indicates both components referring to intercultural competence and the reflective practices employed in the workshop.

\section{Themes}

\subsection{Multiperspectivity}

One of the most apparent recurring themes in the discussions and reflection papers of the students was multiperspectivity, often referred by students in relation to its importance for adaptation. Students stated that they found themselves almost conditioned to think according to their cultures when they were abroad. In almost all of the critical incidents, the main problem was seen to be originating from having one cultural perspective to evaluate events. Therefore, it was concluded by the students that the crucial thing was to be able to adapt to differences and to increase one's multiperspectivity. This is similar to the finding of Schnickel (2014) who states that his students' main comment was "Being different is not bad or wrong" (p.71). In this study, this point of view was stated by S3 as "Being different is fine, we do not have to be similar. I just need to adapt to where I am." Therefore, having to deal with cultural differences was seen as a matter of adaptation to different views and practices rather than a source of problems, which is a significant attitude for intercultural awareness (Barrett, Byram, Lazar, MompointGaillard \& Philippou, 2013).

In the incident titled 'On the Bus', S1 wrote about her experience of travelling on the bus in a city center of Poland. One day, when she saw an old lady getting on the bus, she stood up and wanted to give her seat to the lady. This behavior is regarded as showing respect for the elderly in Turkish culture and is generally appreciated. However, the Polish lady did not accept to have a seat and looked surprised 
with such offer. Instead, she preferred standing up, which made S1 feel upset. S1 stated that, in similar situations after this incident, she did not offer her seat to anyone, thinking that she had to adapt to the Polish culture. In reflective classroom discussions, students remarked that this incident may not only be due to different views of respect in the two cultures, but it could also originate from different understandings of the concept of 'old' attributed to people. Based on their observation, S1 and S2 stated that, compared to the Turkish ladies above a certain age, the elderly Polish ladies took care of themselves better and gave more importance to their physical appearance. Therefore, students commented that standing up on the bus could be associated with being energetic and fit, while accepting a seat could be seen as the opposite. Such kind of comments of the students on the incident from different viewpoints indicate multiperspectivity and cognitive flexibility which are components of intercultural competence as stated by Barrett et al. (2013).

Another incident that caused discussions on multiperspectivity was titled 'Pilgrimage of Rachela'. S3 was in Portugal when she met Rachela who was dressed as an ordinary person. S3 learned that Rachela was a Christian pilgrim who started her journey in Italy and was travelling to specific churches on her own to practice pilgrimage. S3 was very surprised as she found this kind of pilgrimage very different from the Muslim practice of pilgrimage. S1 and S2 chose this incident to reflect on in their reports and stated that they knew nothing about Christian pilgrimage before reading this incident. S2's words show curiosity and eagerness to learn about different cultural practices: "I believe that there are so many people who are not aware of Christian pilgrimage like me. I always like learning new things about other cultures. This was new information for me so I really found this incident important." S1 commented that walking to sacred places as a pilgrim seemed to have a sense of unification with one's true existence in both religions. She believed that if people talked about such kind of similarities in belief systems, there would be less hostility towards differences in the world. When viewed from the perspective of intercultural learning, the reflections of the students demonstrate comparing and contrasting of values and cultural practices which leads to a realization of the importance of decentring from one's own viewpoints (Barrett et al., ibid.).

The importance of multiperspectivity and adaptation ability was also highlighted by students in relation to personal development. Difficult situations were seen as events which increased the students' problem-solving skills and their awareness about differences. In classroom discussions, the students stated that "Life is not always pink. Although we experienced problematic situations, the next time we experience it again we know what we should do." This finding is consistent with Steinwidder's (2016) study in which it was found that "the post-study abroad context is especially relevant for learners' interpretations of the lasting effects of their personal development" (p. 16). Such comments of the students also show a gradual development of coping strategies and action-orientation fostered by experiential learning in sojourn contexts.

Moreover, some incidents opened up discussion about the long-term effect of multiperspectivity. It was commented by the students that while they adapted to the norms of life abroad, they found themselves adapting to the norm when they came back to Turkey. For instance, in the incident about differences in personal space titled 'Waiting in Queue', S2 stated that the Polish way of waiting in queue was different from the Turkish norm. In Poland, people paid attention to keep longer distance in between themselves in a queue compared to Turkey. While he adapted to this norm in Poland, he felt the need to change this behaviour after he returned. This was because people waited at a closer distance in Turkey. He said: "For me, queuing in Turkey was like a nightmare after I came back from Poland, but nobody saw any problems with that. After some time, I adapted to the Turkish norm again." Such kind of behavioural adaptation ability, which is an element of intercultural competence (Barrett et al., 2013), was seen necessary by the students for adaptation not only in a new culture, but also in one's own culture after coming back from the sojourn stay.

\subsection{The Similarity of Experiences}


By reading about each other's experiences and having discussions on them, the students realized how their experiences were similar to each other. When classified based on the Iceberg Model of Culture, it was seen that out of 27 incidents, 9 of them (33\%) belonged to Section A which represented cultural issues which were easy to recognise. 6 of the incidents (22\%) belonged to both Section A and B, 6 of them (22\%) belonged to Section B and C, and $6(22 \%)$ of them belonged to Section C (See Appendix II). This indicates a majority of incidents $(66 \%)$ representing elements of culture which are not easily recognisable and are represented as taking place below the surface in the Iceberg Model of Culture.

It was seen in almost $60 \%$ (16 out of 27) of the reflection reports that students preferred to write about incidents which reminded them of a similar experience that they had experienced. This shows that motivation and self-confidence for reflection are enhanced by by peer discussions and finding out similar experiences. The same was stated by S3 as "When I saw that we had similar experiences, my motivation to share more incidents increased. Besides, as we were all raised in Turkey, the similarity of experiences made it clear that the problematic situations were due to cultural differences." S2 said: "I used to think that these incidents only happened to me. I had not shared them with anyone before. Seeing that my friends also had similar experiences gave me a big relief and confidence to discuss more incidents. " S1 reported a similar opinion as "after sharing my experiences and hearing the comments of my friends and my teacher about them, I was encouraged to share more experiences." This remark shows the important role of the faciliatator for ensuring a supportive learning environment and effective critical reflection in applied learning contexts (Ash \& Clayton, 2009). S1 added that it was fun to talk about the similar experiences caused by unexpected small misunderstandings. The benefit of sharing personal narratives and finding out similar experiences for enabling discussions among students is confirmed by Jackson (2005) who states that "anonymous excerpts from their diaries provided further stimulus for some very lively and reflective discussions of both positive and negative experiences" (p. 168). The students' comments on increased motivation to share also exemplifies the benefit of using critical incidents stated by Dant as (1995) 'It is not unusual to find that a small detail of one person's experience throws light on unnoticed aspects of other students' experiences, which then can be identified and analyzed as critical points of learning” (p. 146).

One of the common experiences was the problems caused by the students' lack of proficiency in the foreign language spoken in the country they stayed. Before their sojourn experience, the students had assumed that people would speak English in public places. However, they found that people either did not know English, or they preferred speaking their native langauge instead. This issue caused problems especially when buying food at the market or when they had to buy tickets for transportation. It indicates the importance of preparation for the sojourn experience before departure, which includes having knowledge about the vocabulary likely to be necessary in daily life situations. It can also be concluded that proficiency in English should not be taken for granted in intercultural encounters, despite the lingua franca status of English.

Another type of experience that the students found common in the collection of incidents was the importance of culture-specific knowledge. Students commented that if you don't know some specific knowledge related to the public life in the foreign country, you can face problems. An incident related to this fact was finding out that shops were closed on Sundays. S3 noted that she experienced such an incident which caused a big diffculty for her in Barcelona, and stated that it is an important specific knowledge that should be known by people planning to travel to Spain. S2 experienced a similar situation in Poland and after that he made a search on the internet about the Trade Ban days in order not to have the same problem again. This shows an awareness of doing further search about intercultural problems which is an important skill to develop for intercultural reflection according to the AIE (Byram et al., 2009).

It is worth noting that critical incidents related to culture-specific knowledge included not only the ones related to the foreign country where the students stayed, but also those related to other cultures. Misunderstandings caused by body language was one of such issues. In the incident titled 'Nodding', 
S2 reported how his nodding caused a misunderstanding while he was once listening to his Chinese friend. He was rapidly nodding his head to show that he was following his friend, as he used to do when talking to his Turkish friends. However, after his friend stopped talking at the middle of the conversation, he understood that there was a misunderstanding. His Chinese friend told him afterwards that this body language meant "it is all understood, there is nothing more to say" in her culture. Such kind of incidents show the significance of having knowledge about other cultures' verbal and nonverbal communicative practices, which indicates communicative awareness (Barrett et al., 2013).

\subsection{Working with Critical Incidents}

The students emphasized the advantages of using critical incidents as the main materials of the workshop. Related to this benefit, S3 stated that "I got the chance to realize the advantages of using critical incidents. I think it is a useful technique to share our ideas and compare our experiences." Similarly, S2 said: "Before having discussions about our experiences in the workshop, I had some question marks in my mind about the reason of using critical incidents." His remarks show a gradual development of critical thinking skills: "At the first meeting, I had a different perspective of interpreting the incidents. But now I have gained the ability of analyzing a critical incident. With this ability, I can easily understand the real reason of why it happened." In terms of the benefits of working with critical incidents in the future, S2 said: "It will help me to overcome my problems related to cultural differences in the future. Also, next time I go abroad, I will be aware of most of the things and I believe I will not face bad incidents." S1's comments show that working with critical incidents is advantageous to deal with cultural problems not only in study abroad contexts, but also in one's own environment: "I live in a touristic region of Turkey. With the help of the critical incidents in the workshop, I can understand the actions of the tourists that I encounter when I go back to my hometown."

Students thought that rather than reading experiences of other people, it was more advantageous to read each other's incidents. S2 remarked as "If we read other people's experiences, it would not have the same effect of reading our own experiences. Some details about the event would be missing, and we would not have the chance to analyze it well enough. "Working with one's own experiences also appears to be advantageous for developing interpersonal communication skills. S3 said: "Hearing the comments of my friends on my critical incidents developed my ability to think more critically about their reason. It also had a positive influence on my ability to analyze a problematic event in my daily life." Similarly, $\mathrm{S} 1$ commented as "It was very advantageous for me not only in terms of analyzing cultural problems, but also my personal relationships in my everyday life." These comments of the students show the benefit of analyzing problematic events for improving one's interpersonal communication skills. This point is highlighted by Tracy (2002) as “..., you should find yourself better able to be the kind of person you are seeking to be and to more satisfactorily manage the social, work, public, and intimate relationships about which you care" (p. 5). S1's comments also show a willingness for actionorientation (Barrett et al., 2013) enhanced by working with critical incidents. She said: "While reading my incidents, I realized that I spent most of my time with my Turkish friends and almost isolated myself from foreign people. I regret this and want to find new opportunities to go abroad again so much. "Such comments also exemplify the benefits of reflective writing stated by Dressler et al. (2018) as giving the students the ability to "surface information or experiences that they had not focused on or had not taken the time to process" (p. 490).

Knowing that the final version of their incidents will be read by other students increased the students' motivation and confidence to write and share more. S2 said: "It is good to know that reading my incidents will help other students see that they are not the only ones facing difficulties. They will be more tolerant towards differences and more solution-oriented." S3 said: "Someone who reads my critical incidents will know what to do when he/she faces similar situations. Writing my experiences for other students increased my motivation to write in more detail." Her words indicate that her sojourn experiences almost gained a new meaning in the workshop: "Before this workshop, they were just 
memories for me." Similarly, S1 commented as "While having discussions on our critical incidents, I remembered an incident I experienced that is worth writing. "This comment shows increased motivation to write more incidents as well as an ownership of one's experiences.

All of the students found it beneficial that they had discussions on the classification of their incidents based on the Iceberg Model of Culture. One example of such discussions was about the incident titled 'Eating during Lesson'. In this incident, S2 talks about how surprised he was to find that it was normal for the students to eat something during the lesson in Poland. When he saw some of his friends in class talking to the teacher while chewing food, he was afraid that the teacher would be very angry as this is generally a disrespectful behaviour in Turkish culture. However, the teacher did not show such reaction. While this is an issue which can be recognised easily in the foreign culture, the students questioned whether it can also be discussed in terms of the differences in understanding of respect in the two cultures. This opened up a discussion about the differences in what is regarded as appropriate and inappropriate behaviour in certain contexts. Similarly, the students commented that 'Chasing a Bee', written by S2, could be discussed both referring to surface and deep culture (see Appendix III).

Another example which caused discussions about whether the incident was an example of surface culture or deep culture was 'Bom Dia!' written by S3 (see Appendix III). In this incident, it was at first strange for S3 that people greeted her in public places no matter they knew her before or not. This is different from the norm in Turkey where people generally only greet those that they know. If only seen as a difference in greeting styles, this could be an element of surface culture. However, the students had comments about their observation that while it was common to see people smiling and greeting each other, it was not easy to form long-lasting friendships. Therefore, this topic led to discussions on the nature of relationships in individualistic and collectivistic cultures, which is related to deeper values (Hofstede, 2001).

\subsection{Using Structured Models}

The students' comments reveal the advantage of working with a structured framework for reflection, which is also emphasized by Williams (2017). Reflection was established throughout the workshop both through Kolb's Experiential Learning Cycle for classroom discussions and the CCR Model for reflective writing. About the activities in the classroom, S1 said: "The questions our instructor asked and discussions with my friends helped me to refresh my memories." Also, S3 commented as "We told our ideas freely and speculated about our memories by using various techniques such as brainstorming, imagining, question-answer and discussions. These helped me to change my perspective about the incidents." These comments show the advantage of using an experiential learning model in the workshop.

The CCR framework provided a structure for the students to revise their incidents which would be the outcome of the workshop. The students stated that rewriting incidents by using a reflective framework was helpful to make them think about aspects of the event they did not consider before. This finding is confirmed in previous literature (Erdem Mete, 2018). S3 said: "The detailed components of the CCR Model made me to think about my incident again from different perspectives. I realized the truth behind my incidents." This shows that using the CCR Model increased the students' critical thinking skills. S2 said: "The CCR Model provided guidance to show me what was missing in my written incident. It was an ideal tool to give my incident its final version." As another benefit, S1 said: "The CCR Model helped me to organise my thoughts about the incident. The first version of my written incidents did not have a proper organisation. It was as if I wrote whatever came to my mind about the experience." Other remarks of S1 show that the CCR Model fostered an understanding of the importance of having empathy for the other which is a component of intercultural competence: "By using the CCR Model, I have learned that making judgements about intercultural incidents without evaluating the situation for both sides has a negative consequence such as misjudgements and misunderstandings." 
On the other hand, all of the students stated that this revising and rewriting experience was not easy for them. S2 said: "I found it difficult to remember the incident in a detailed way. This was either because the incident did not involve all the required components of the CCR Model, or I could not remember the incident well." The same comment was stated by the other two students, which points to the fact that reflection can become difficult after a certain period of time. The comments of S3 highlight the benefit of working with a stuctured framework at the beginning of the writing experience: "I wish we wrote our incidents before the workshop by using the CCR Model. I found it difficult to write incidents without a framework. Once we started using the framework, it became clear for me what to write."

The benefit of using a reflective writing framework is seen in the revised incidents of the students as well as in their comments. All of the students made additions to their previous incidents although they were told that they did not have to change anything if they thought the original version was good enough. It was seen in almost $90 \%$ of the incidents that the students added information to the original version about elements related to the 'Make Meaning' component of the CCR framework. As seen in sample revised critical incidents in Appendix III, the added parts mainly refer to "Think of what knowledge you wish you had had", "Note what was good or bad about the experience", "Describe how you were challanged in this situation, "Specify what you learned about yourself, others and the world around you", "Describe how you feel about the situation now" and "Recall what supports you should have used." This indicates that the main component of the CCR framework which established reflective learning in the workshop was 'Make Meaning', which shows a development in critical thinking skills of the students. This criticality demonstrated in the students' revised critical incidents can also be claimed to be enhanced by the reflective discussions in the workshop. In their discussion on the benefits of using critical incidents, this point is highlighted by McAllister et al. (2006) as "Each retelling enabled higher levels of insight to be developed, which could then be generalized to personal and professional constructions of 'the self' and 'other'”' (p. 378).

As the CCR Model was especially designed for pre-service teachers, it was suited for the context of the study where the majority of the participants, S1 and S3, wanted to be English teachers. S1 stated that, in terms of the insights she gained in the workshop, listening to the students' experiences carefully and respectfully, helping them to realize that their perspectives on different issues are valuable and having an objective attitude towards different opinions are some of the things that she would like to bring to her own teaching in the future. S3 commented that she would like to use activities that would help her learners to improve their critical thinking and problem solving skills as in the post-sojourn debriefing workshop. These remarks of the students show that the CCR Model can have positive outcomes for pre-service teachers and the model can be used in teacher education.

In this study, it was seen that the Iceberg Model of Culture was found a very beneficial supplementary model by the students. Therefore, it can be claimed that it functioned as another framework to structure the students' thoughts. Rather than a random reading of the incidents, the classification of the critical incidents based on a set criteria was especially found useful by the participants. All of the students referred to the Iceberg Model of Culture when talking about the benefits of working with critical incidents. S3 stated that "Classifying our incidents based on the Iceberg Model of Culture made abstract concepts more concrete for me. It was like a tool that helped me to analyze cultural differences." S2 said: "I think that the Iceberg Model of Culture was the key element of this workshop. By using this model, I could easily classify our incidents and understand the reason of why they occured." S1 said: "I am very glad to learn about this model which made it fun for me to decide which section was more appropriate for our incidents." Especially for students who do not have prior cross-cultural training, providing models such as the Iceberg Model of Culture which enables to see the big picture of culture appears to be useful for supplementing detailed reflective writing frameworks. 


\section{Conclusions}

The study shows the importance of structured reflection in post-sojourn debriefing workshops which include reflective writing practices. Classroom discussions based on Kolb's (1984) Experiential Learning Model were supplemented by the CCR Model (Dressler et al., 2018) designed for reflective writing about sojourn experiences. In this way, reflective writing was integrated in the experiential activities throughout the workshop and this enabled continuous critical thinking on the sojourn experiences. Using participants' own critical incidents as the material of the workshop was beneficial especially for providing a supportive learning environment. Motivation and confidence to write and share sojourn experiences, being critical about the causes of problematic incidents, thinking about neglected aspects of such incidents appeared to be enhanced in the workshop. Multiperspectivity, openmindedness, willingness to emphatise with other cultural orientations, cognitive flexibility, behavioral adaptation, decentring from one's viewpoints, and communicative awareness were aspects of intercultural competence which were revealed in the post-sojourn workshop. With such intercultural learning outcomes, the findings of literature on the benefits of post-sojourn interventions are confirmed. Apart from intercultural learning, personal development and improved interpersonal communication skills were other aspects of learning which appeared in the workshop. Therefore, the significance of implementing post-sojourn debriefing workshops for EFL higher education students is highlighted.

The study also confirms findings of previous literature on the advantages of using critical incidents for intercultural reflection (McAllister et al., 2006), as well as the significance of providing structure for reflective writing practices (Williams, 2017). It shows the benefits of combining reflective writing activities with group discussions in post-sojourn debriefing workshops. Carrying out reflective writing activities about cross-cultural experiences with a group of students, rather than working individually, can be claimed to be especially advantageous. From the perspective of English language teaching, working with critical incidents in the context of a post-sojourn debriefing workshop enabled an integration of reading, writing and speaking activities for EFL learners. In future studies, adaptation and implementation of similar integrated activities by using critical incidents in EFL higher education contexts can be investigated. The use of experiential learning and reflective writing models in postsojourn debriefing workshops can be explored with larger groups of EFL students and in the context of teacher education.

\section{References}

Andrew, M. (2012). Like a newborn baby: Using journals to record changing identities beyond the classroom. TESL Canada Journal, 29(1), 57-76.

Arthur, N. (2001). Using critical incidents to investigate cross-cultural transitions. International Journal of Intercultural Relations, 25(1), 41-53.

Ash, S. L. \& Clayton, P. H. (2009). Generating, Deepening, and Documenting Learning: The Power of Critical Reflection in Applied Learning, Journal of Applied Learning in Higher Education, 1, 25-48.

Barrett, M., Byram, M., Lazar, I., Mompoint-Gaillard, P., \& Philippou, S. (2013). Developing intercultural competence through education. Strasbourg: Council of Europe. Retrieved from http://www.coe.int/t/dg4/education/pestalozzi/Source/Documentation/Pestalozzi3.pdf

Battles, L. A. (2004). Promoting Language and Culture Learning in an EFL Context. MA TESOL Collection.158. Retrieved from https://digitalcollections.sit.edu/ipp_collection/158 
Baxter, J. \& Ramsey, S. (1996). Improvising Critical Incidents. In H. N. Seelye (Ed.) Experiential Activities for Intercultural Learning (pp. 211-218). Boston: Intercultural Press.

Bennett, M. J. (1995). Critical Incidents in an Intercultural Conflict-Resolution Exercise. In S. M. Fowler \& M. G. Mumford (Eds.). Intercultural Sourcebook: Cross-Cultural Training Methods (pp. 147156). Boston: Intercultural Press.

Boggu, A. T. \& Sundarsingh, J. (2016). The Impact of Experiential Learning Cycle on Language Learning Strategies, International Journal of English Language Teaching, 4(10), 24-41.

Byram, M., Barrett, M., Ipgrave, J., Jackson, R. \& Mendez Garcia, M. (2009). Autobiography of intercultural encounters. Language Policy Devision: Council of Europe. Retrieved from https://rm.coe.int/autobiography-of-intercultural-encounters/16806bf02d

Callen, B. (1999). Cross-cultural capability: The student diary as a research tool. In D. Killick \& M. Parry (Eds.). Languages for Cross-Cultural Capability (pp. 241-248). Leeds: Leeds Metropolitan University.

Dant, W. (1995). Using Critical Incidents as a Tool for Reflection. In S. M. Fowler \& M. G. Mumford (Eds.) Intercultural Sourcebook: Cross-Cultural Training Methods (pp. 141-146). Boston: Intercultural Press.

Dressler, R., Becker S., Kawalilak C. \& Arthur N. (2018). The cross-cultural reflective model for postsojourn debriefing, Reflective Practice, 19(4), 490-504.

Engelking, T. L. (2018). Joe's Laundry: Using Critical Incidents to Develop Intercultural and Foreign Language Competence in Study Abroad and Beyond, Frontiers: The Interdisciplinary Journal of Study Abroad, 30(2), 47-62.

Erdem Mete, D. (2018). Using Autobiography of Intercultural Encounters as a Framework to Write Narratives of Intercultural Encounters, Selçuk University Journal of Social Sciences Institute, 39, 201 215.

Farrell, T. S. C. (2013). Critical incident analysis through narrative reflective practice: A case study, Iranian Journal of Language Teaching Research, 1(1), 79-89.

Flanagan, J. C. (1954). The Critical Incident Technique, Psychological Bulletin, 51(4), 327-358.

Gibbs, G. (1988). Learning by doing: A guide to teaching and learning methods. London, UK: Further Education Unit (FEU).

Gómez Rodríguez, L. F. (2015). Critical Intercultural Learning through Topics of Deep Culture in an EFL Classroom, Ikala, Revista de Lenguaje y Cultura, 20(1): 43-59.

Hall, E. T. (1976). Beyond Culture. Garden City, NY: Anchor Press.

Hepple, E. (2018). Designing and implementing pre-sojourn intercultural workshops in an Australian university. In J. Jackson \& S. Oguro (Eds.). Intercultural Interventions in Study Abroad (pp. 18-36). New York: Routledge.

Hofstede, G. (2001). Cultures's Consequences: Comparing Values, Behaviors, Institutions and Organizations Across Nations. Thousand Oaks, CA: Sage.

Jackson, J. (2005). Assessing Intercultural Learning through Introspective Accounts, Frontiers: The Interdisciplinary Journal of Study Abroad, 11, 165-186.

Johns, C. (2010). Guided reflection: A narrative approach to advancing professional practice. Oxford, UK: Wiley-Blackwell. 
Kilianska-Przybylo, G. (2012). "Stories from Abroad"-Students' Narratives about Intercultural Encounters, TESOL Journal, 6, 123-133.

Knutson, S. (2003). Experiential Learning in Second-Language Classrooms. TESL Canada Journal, 20(2), 52-64.

Kolb, D. (1984). Experiential Learning: Experience as the Source of Learning and Development. Englewood Cliffs: NJ Prentice-Hall, Inc.

Koyama, Y., Matsumoto, K., \& Ohno, H. (2012). Teaching intercultural competence and critical thinking in EFL classes in Japan- Developing a framework and teaching material. Proceedings of the 17th Conference of PanPacific Association of Applied Linguistics (pp. 73-74). Retrieved from http://paaljapan.org/conference2012/proc_PAAL2012/pdf/poster/P-13.pdf

Lee, L. (2018). Employing telecollaborative exchange to extend intercultural learning after study abroad. In J. Jackson \& S. Oguro (Eds.). Intercultural Interventions in Study Abroad (pp. 137-154). New York: Routledge.

McAllister, L., Whiteford, G., Hill, B., Thomas N., \& Fitzgerald, M. (2006). Reflection in intercultural learning: examining the international experience through a critical incident approach, Reflective Practice, 7(3), 367-381.

McKinnon, S. (2018). Foregrounding intercultural learning during study abroad as part of a modern language degree. In J. Jackson \& S. Oguro (Eds.) Intercultural Interventions in Study Abroad (pp. 103118). New York: Routledge.

Méndez Garcia, M. C. (2017). Intercultural reflection through the Autobiography of Intercultural Encounters: students' accounts of their images of alterity, Language and Intercultural Communication, 17(2), 90-117.

Patton, M. (2002). Qualitative research and evaluation methods. California: Sage Publications, Inc.

Pellegrino, V. A. (1998). Student perspectives on language learning in a study abroad context. Frontiers: The Interdisciplinary Journal of Study Abroad, 4(2), 91-120.

Rolfe, G., Freshwater, D., \& Jasper, M. (2001). Critical reflection for nursing and the helping professions: A user's guide. Basingstoke, UK: Palgrave.

Schnickel, J. (2014). Student-Generated Critical Incidents Prior to Studying Abroad. Jissen Women's University FLC Journal, 9, 61-73.

Spencer-Oatey, H. \& Davidson, A. (2013). 3RA Intercultural Learning Journal Template: A tool to help recording and reflection on intercultural encounters. GlobalPAD Open House. Retrieved from http://www2.warwick.ac.uk/fac/soc/al/globalpad/openhouse/interculturalskills/

Steinwidder, S. (2016). EFL learners' post-sojourn perceptions of the effects of study abroad, Comparative and International Education, 45(2), Article 5. Retrieved from http://ir.lib.uwo.ca/cieeci/vol45/iss $2 / 5$

Strauss, A. \& Corbin, J. (1998). Basics of qualitative research: Techniques and procedures for developing grounded theory. Thousand Oaks, CA: Sage.

Thiel, T. (1999). Reflections on Critical Incidents, Prospect, 14(1), 44-52.

Tracy, K. (2002). Everyday Talk. New York: Guilford Press.

Tran T. Q. T., Admiraal W. \& Saab N. (2019): Effects of critical incident tasks on the intercultural competence of English non-majors, Intercultural Education, 30(6), 618-633. 
Utley, D. (2004). Intercultural Resource Pack: Intercultural communication resources for language teachers. Cambridge: Cambridge University Press.

Wagner, K. \& Magistrale, T. (1999). Writing across Culture: An Introduction to Study Abroad and the Writing Process. New York: Peter Lang Publishing Co.

Walker, J. (2015). Using Critical Incidents to Understand ESL Student Satisfaction, TESL Canada Journal, 32(2), 95-111.

Wight, A. R. (1995). The Critical Incident as a Training Tool. In S. M. Fowler \& M. G. Mumford (Eds.) Intercultural Sourcebook: Cross-Cultural Training Methods (pp. 127-140). Boston: Intercultural Press.

Williams, T. R. (2017). Using a PRISM for Reflecting: Providing Tools for Study Abroad Students to Increase Their Intercultural Competence. Frontiers: The Interdisciplinary Journal of Study Abroad, 29(2), pp: 18-34.

\section{APPENDIX I. Cross-Cultural Reflection Model (Linear)}

\section{Imagine}

The facilitator will walk you through an imagery activity that is intended to focus your mind before we begin the workshop. Listen carefully to the instructions.

\section{Describe}

Describe a significant experience or event from your [program] placement

Describe the context (location, your role, others' roles, the purpose)

Call to mind your assumptions, expectations, the supports you had and your prior knowledge and experience going into this situation

What happened?

\section{Reflect}

Describe your feelings and the felings of others

Describe what sticks in your mind about this experience

Mention what values surfaced for you during this experience and in what ways

Note what consequences your actions had for yourself and others

Specify how this experience connects to previous experiences

Recall which supports you used

\section{Make Meaning}

Tell what is significant about the experience for you now

Think of what knowledge you wish you had had

Note what was good or bad about the experience

Describe how you were challenged in this situation

Specify what you learned about yourself, others and the world around you

Recount what key insights you have gained

Describe how you feel about the situation now

Recall what supports you should have used

Imagine how you could have responded differently

\section{Take Learning Forward}

Describe the cross-cultural competencies/ abilities you used, gained or enhanced through this experience Imagine how any insights you have gained might impact your teaching/ your future

Share with a partner the answers to the following two questions:

1.What cross-cultural competencies did you use, gain or enhance through this experience?

2.How will you bring the insights gained into your teaching?

(Adapted from: Dressler et al., 2018) 
APPENDIX II. Classification of the Critical Incidents based on the Iceberg Model of Culture

\begin{tabular}{|c|c|c|c|c|c|}
\hline \multirow{2}{*}{$\begin{array}{l}\text { Session } \\
\text { Number }\end{array}$} & \multirow[t]{2}{*}{ Title of the Incident } & \multicolumn{3}{|c|}{ Participants } & \multirow{2}{*}{$\begin{array}{l}\text { Section of the } \\
\text { Incident }\end{array}$} \\
\hline & & S1 & S2 & $\mathbf{S 3}$ & \\
\hline 1 & Sunday Morning & & & $\mathrm{x}$ & A \\
\hline 1 & What to Eat & $\mathrm{x}$ & & & A \\
\hline 1 & Azulejo & & & $\mathrm{x}$ & $\mathrm{A}$ \\
\hline 1 & Real Pizza & $\mathrm{x}$ & & & A \\
\hline 1 & Weekend School & & $\mathrm{x}$ & & A \\
\hline 1 & Sao Joao Feast & & & $\mathrm{x}$ & $\mathrm{A}$ \\
\hline 1 & Chasing a Bee & & $\mathrm{x}$ & & $\mathrm{A}$ \\
\hline 1 & Sleeping at the Airport & $\mathrm{x}$ & & & $\mathrm{A}$ \\
\hline 1 & Eating during Lesson & & $\mathrm{x}$ & & $\mathrm{A}$ \\
\hline 2 & Bom Dia! & & & $\mathrm{x}$ & A-B \\
\hline 2 & Nodding & & $\mathrm{x}$ & & A-B \\
\hline 2 & Waiting in Queue & & $\mathrm{x}$ & & A-B \\
\hline 2 & Buying a Ticket & $\mathrm{x}$ & & & A-B \\
\hline 2 & Shopping in Portugal & & & $\mathrm{x}$ & A-B \\
\hline 2 & Knowing English & $\mathrm{x}$ & & & A-B \\
\hline 3 & Silent School & & $\mathrm{x}$ & & $\mathrm{B}-\mathrm{C}$ \\
\hline 3 & Wedding & & $\mathrm{x}$ & & B-C \\
\hline 3 & A Cup of Coffee & & & $\mathrm{x}$ & B-C \\
\hline 3 & Alone in Silence & & $\mathrm{x}$ & & $\mathrm{B}-\mathrm{C}$ \\
\hline 3 & On the Bus & $\mathrm{x}$ & & & $\mathrm{B}-\mathrm{C}$ \\
\hline 3 & Dormitory & $\mathrm{x}$ & & & $\mathrm{B}-\mathrm{C}$ \\
\hline 4 & Rules, Rules, Rules! & & $\mathrm{x}$ & & $\mathrm{C}$ \\
\hline 4 & What will People Say? & & $\mathrm{x}$ & & $\mathrm{C}$ \\
\hline 4 & Mayor of the City & & $\mathrm{x}$ & & $\mathrm{C}$ \\
\hline 4 & Pilgrimage of Rachela & & & $\mathrm{x}$ & $\mathrm{C}$ \\
\hline 4 & Problem Turks! & $\mathrm{x}$ & & & $\mathrm{C}$ \\
\hline 4 & Challange & & & $\mathrm{x}$ & $\mathrm{C}$ \\
\hline
\end{tabular}

(A: Surface Culture, B: Just Below Surface Culture, C: Deep Culture)

\section{APPENDIX III. Sample Critical Incidents}

(What is written in bold shows the additions the students made to the original criticals incident after the post-sojourn workshop sessions)

BOM DIA! 
I woke up early and got prepared for my first day at work in Portugal. I was living in an apartment building which had three floors. When I walked out of my flat, I met an old Portuguese lady who was living on the second floor. Although this lady had not seen me before, she said "bom dia!" and walked away. Hearing my neighbour say "good morning" made me happy because I had left my country to live in this foreign country a short time ago and I was trying to adapt to this new culture. The shuttle vehicle of my company was collecting people from a bus-stop in front of a church near my house. When I was walking towards the church, a middle-aged man said "bom dia!" again. I replied as "bom dia" too, and went on walking. I knew that "bom dia" meant "good morning" in Portuguese but I found it surprising that someone who did not know me greeted me like this. I ran to the bus-stop in order to catch my shuttle vehicle and I saw lots of people waiting. Many people in the crowd smiled and said "bom dia" to me and I replied back in the same way. As it was my first day at work, I thought everybody waiting there must be working at the same office with me. When the shuttle vehicle arrived, I was the only one getting on it. So, I understood that these people did not work at the same place. At first I had found it weird that people who did not know me said "good morning" to me because in my country people only greet those that they know. During the time that I lived in Portugal, when people said "bom dia", I smiled and greeted them in the same way. However, I was never the first to greet someone that I did not know because I had hesitations about it.

\section{CHASING A BEE}

The incident took place at the university. It was a bad experience which I will never forget. I was sitting in a classroom with other students and listening to the teacher. It was hot inside the classrom so one of the students opened a window. Soon after, a bee flew in through the open window. The bee was making it impossible to teach for the teacher and one of the students was afraid that it would sting her. A Turkish exchange student like me finally took a notebook to kill the bee. Surprisingly, the Polish students protested, saying that he could not kill it. I did not know what to do, so I just kept my silence. Polish students ended up chasing it out the window. The class continued from where it had stopped, but my Turkish friend was a bit embarrassed. I was also shocked because my friend and I did not expect this kind of reaction from the Polish students. I felt sorry for my friend. I wish he had known this before so that he would have been more careful about it. I think he just wanted to help and maybe he was not trying to kill the bee. Value of animals was a little bit different in Poland compared to Turkey. On that day we learned a lesson: all lives matter even if you are a bee. 


\section{APPENDIX IV. The Iceberg Model of Culture}

1. Surface: Observable behavior of others, things we can see and touch etc.

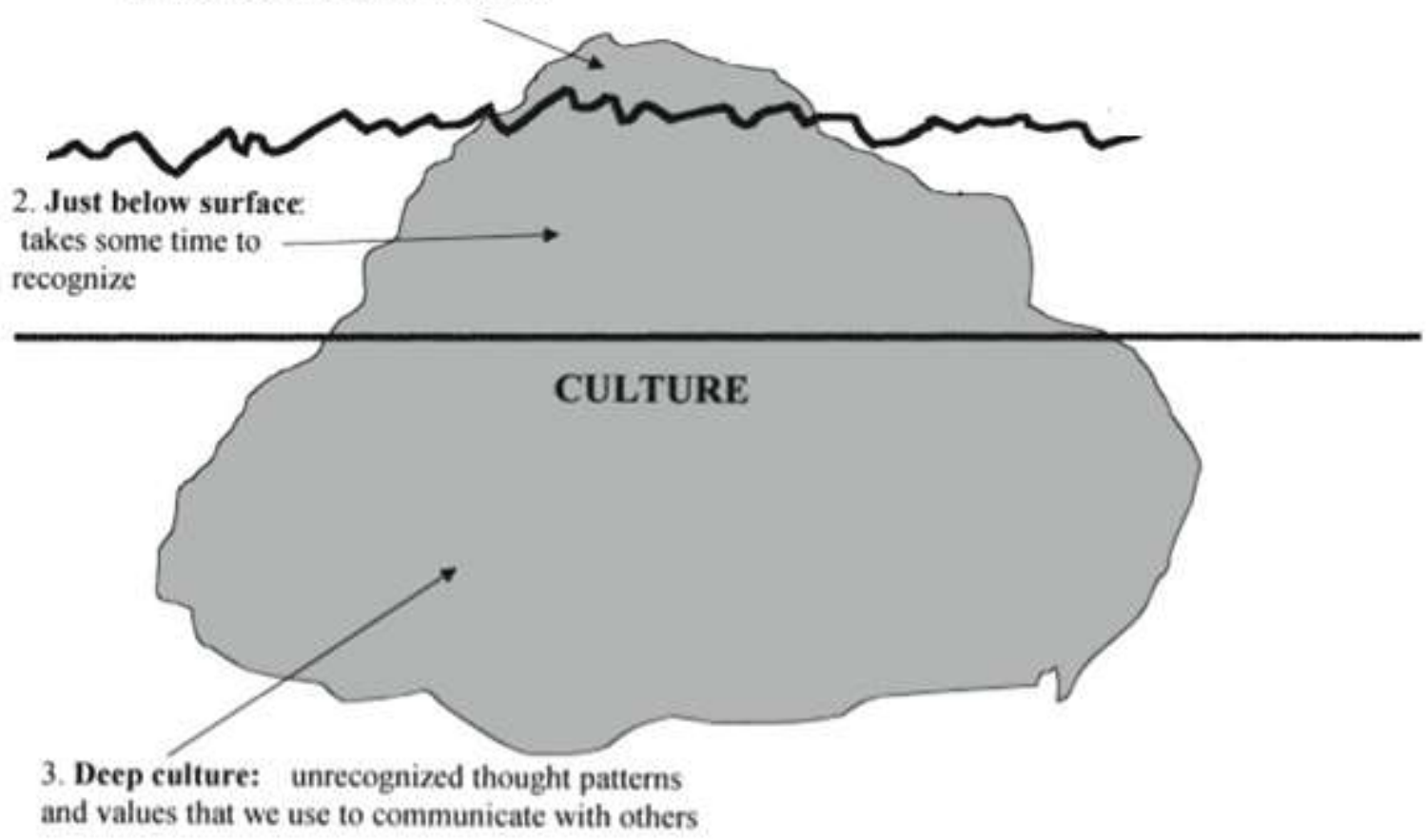

(Adapted from: http: //usconversation.com) 


\title{
Yansıma ile öğrenme: İngilizce öğrenen üniversite öğrencilerine yönelik
}

\author{
yurtdışı deneyimi sonrası çalıştayı ile ilgili bir örnek olay
}

\begin{abstract}
$\ddot{O} \mathbf{z}$
Deneyimsel öğrenme aktiviteleri, İngilizce öğretimi de dahil olmak üzere, eğitimde sıkça kullanılmaktadır. Yurtdışı eğitimi programları, deneyim ile öğrenme açısından eşsiz firsatlar sunmaktadır. Yurtdışı deneyimlerinden öğrenmeyi en üst seviyeye getirmek, yurtdış eğitimi programları sunan yükseköğretim kurumlarının başta gelen hedeflerinden olmalıdır. Bu amaçla, yurtdışı deneyimi sonrası çalıştayları düzenlemek çok önemlidir. Bu nitel örnek olay incelemesinde, Kolb’un (1984) Deneyimsel Öğrenme Modeli, İngilizce'yi yabancı dil olarak öğrenen üç Türk üniversite öğrencisine yönelik bir yurtdışı deneyimi sonrası çalıştayı düzenlemek için kullanılmıştır. Çalıştay, yurtdışı deneyimi ile ilgili yansıtıcı yazma için geliştirilen Kültürlerarası Yansıtıcı Model (Dressler et al., 2018) ile desteklenmiştir. Çalışmanın katılımcıları tarafından yazılan zorluk yaratan olaylar, çalıştayda kullanılan temel materyalleri oluşturmuş ve yansıma çalışma boyunca kesintisiz bir süreç olarak yer almıştır. Veriler yansıma raporları, yansıma evrakları, yazılı olaylar, mülakat belgeleri ve alan notlarından toplanmıştır. Çalışmanın bulguları, İngilizce öğrenen üniversite öğrencilerine yönelik, yansıtıcı bir yazma modeli ile desteklenmiş yurtdış1 deneyimi sonrası çalş̧tayının özellikle kültürlerarası öğrenmeyi geliştirmek, eleştirel yansımaya olanak sağlamak ve yurtdışı deneyimini paylaşma güdülenmesini arttırmak için faydalı olduğunu göstermiştir. Ayrıca, zorluk yaratan olayların çalıştayda kullanılmasının yansıma için önemli bir rol oynadığına dikkat çekilmiştir.
\end{abstract}

Anahtar sözcükler: Yabancı Dil olarak İngilizce; deneyimsel öğrenme; yurtdışı deneyimi sonrası çalıştayı; yansitıcı yazma; zorluk yaratan olay

\section{AUTHOR BIODATA}

Defne Erdem Mete is a faculty member at the Faculty of Letters, Department of English Language and Literature at Selçuk University. She holds a PhD in English Language Teaching. Her research interests include intercultural communication, environmental awareness in language teaching and teaching Turkish as a foreign language. 